\title{
Prediction of water erosion in a watershed located in southeastern Brazil
}

Guilherme Henrique Expedito Lense ${ }^{1}$

Fernanda Almeida Bócoli²

Rodrigo Santos Moreira3

Ronaldo Luiz Mincato 4

\section{Abstract}

Water erosion modeling is a fast and accurate way to estimate erosion potential in watersheds. Among the models, we have the Revised Universal Soil Loss Equation (RUSLE) which has a simple structure, low implementation cost and can be used with readily available information, contributing to the planning of soil conservation practices. In this context, the objective of the work was to apply RUSLE to estimate water erosion in the Córrego da Laje watershed affluent directly from the reservoir of the Furnas Hydroelectric Plant, located in the south of Minas Gerais, a region of southeastern Brazil. In this region, water erosion is a serious problem that has caused the silting up of the hydroelectric reservoir and the depreciation of water quality. Soil losses were calculated in Geographic Information System based on topographic, edaphoclimatic characteristics, soil cover, and management practices. The average soil loss of the watershed was $26.80 \mathrm{Mg} \mathrm{ha}^{-1}$ year $^{-1}$ with the predominance of highintensity erosive rates ( $>15 \mathrm{Mg} \mathrm{ha}^{-1}$ year ${ }^{-1}$ ). Considering the basin use classes, sediment generation was higher in pasture areas (35.87 $\mathrm{Mg} \mathrm{ha}^{-1}$ year $^{-1}$ ), and in areas under maize cultivation (32.05 Mg ha $^{-1}$ year ${ }^{-1}$ ). As areas with severe erosion are distributed throughout the watershed, a comprehensive water erosion mitigation plan should be adopted to reduce the environmental damage of the process.

Keywords: Soil conservation. Soil coverage. RUSLE.

\section{Introduction}

Water erosion is the main process of degradation of tropical soils, generating negative environmental impacts such as the reduction of soil productive potential, loss of soil microbiota, and emission of greenhouse gases (DECHEN et al., 2015). In the region surrounding the Furnas Hydroelectric Plant (FHP), in southern Minas Gerais, erosion mitigation is one of the greatest challenges for the sustainable management of the area (IGAM, 2013).

In addition to causing silting up of the FHP reservoir, reducing its useful life, water erosion also causes a depreciation of water quality and contamination with mineral fertilizers, since the vast majority of eroded sediments that reach the watercourses of the region are provided with areas with crops (IGAM, 2013). Thus, effective soil conservation measures are needed to control water erosion in the FHP region.

1 Universidade Federal de Alfenas (UNIFAL-MG). Doutorando pelo Programa de Pós-Graduação em Ciências Ambientais. guilherme.lense@unifal-mg.edu.br. Rua Gabriel Monteiro da Silva, 700, Centro, 37130-000, Alfenas, Minas Gerais, Brasil. 
Modeling is a quick and accurate way to assess quantitatively and qualitatively the erosive potential. This technique can be used to design and target effective soil and water conservation measures (OLIVEIRA et al., 2014; WANG et al., 2019). Also, the application of modeling improves the interpretation of soil erosion processes and facilitates the understanding of ecosystem dynamics (ALEWELL et al., 2019).

Among the initially developed models to evaluate the erosive rate, there is the Universal Soil Loss Equation (USLE) (WISCHMEIER; SMITH, 1978) and latter its enhanced version, the Revised Universal Soil Loss Equation (RUSLE) (RENARD et al., 1997). The RUSLE presents a simple structure, with low implementation costs and can be used with readily available information. Because of it, this model is the most used worldwide when talking about the water basin (RENSCHLERA; MANNAERTS; DIEKKRÜGER, 1999; GANASRI; RAMESH, 2016).

The combination of RUSLE with Geographic Information System (GIS) and Remote Sensing, facilitates its use and provides a diagnosis on the spatial distribution of water erosion. The GIS makes it possible to regroup and superimpose several thematic maps, as well as apply mathematical equations for different erosive factors. Using satellite images, digital terrain elevation models and other data, GIS can generate effective results simply and inexpensively (HAIDARA et al., 2019). These results contribute significantly to the planning of soil conservation practices, erosion control and management of areas affected by the erosion process (PRASANNAKUMAR et al., 2012).

In this context, the objective of the work was to apply the Revised Universal Soil Loss Equation to quantify water erosion in the Córrego da Laje watershed tributary directly from the Furnas Hydroelectric Plant reservoir. The study will make it possible to identify the areas most susceptible to erosion, to contribute to the adoption of conservationist soil management.

\section{Material and methods}

\section{Study area}

The Córrego da Laje watershed has an area of 3,951.30 ha, located in the municipality of Alfenas, south of Minas Gerais, the southeastern region of Brazil, at coordinates 45057'7" to 45054'3" O and 21'26'59" at 21032'54" S (FIGURE 1). The area's climate according to the Köppen classification is Tropical Mesothermal $(\mathrm{Cwb})$, with dry winter and temperate summer. The average annual precipitation is $1,500 \mathrm{~mm}$ and the average annual temperature is $22^{\circ} \mathrm{C}$ (ALVARES et al., 2013; INMET, 2019). The soils of the watershed are dystrophic Red Latosols - LVd (71 \%) and eutrophic Red-Yellow Argisol - PVAe (29\%). The digital soil map was prepared based on the soil map of the state of Minas Gerais (UFV et al., 2010) (FIGURE 1).

The land use and occupation map (FIGURE 2A) was based on images from the Landsat-8 Operational Land Imager (OLI) satellite, orbit/point 219/75, selected in the Image Generation Division (INPE, 2019) on May 29, 2019 and, based on high-resolution images from the Basemap tool (ESRI, 2015). The watershed is occupied by: maize $-1,120.74$ ha (28.4\%), pasture - $1,085.25$ ha (27.47\%), coffee -911.93 ha (23.08\%), native forest - 701.46 ha $(17.75 \%)$, eucalyptus -72.84 ha (1.8\%), facilities 31.65 ha $(0.8 \%)$ and water -27.43 ha $(0.7 \%)$. 
Figure 1 - Córrego da Laje watershed localization and soil digital map, Alfenas, South of Minas Gerais, Brazil.

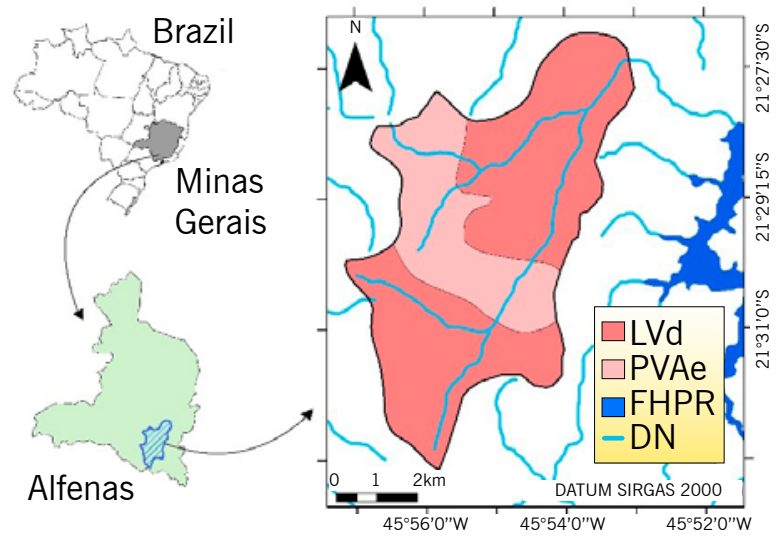

Notes: LVd $=$ Dystrophic Red Latosols, PVAe $=$ Eutrophic Red-Yellow Argisol, FHPR $=$ Furnas Hydroelectric Plant Reservoir and DN = Drainage Network.

Source: Elaborated by the authors (2020).

Figure 2 - Land Use Map (A) Digital Elevation Model (B) and Slope Map (C) of Córrego da Laje watershed, Alfenas, south of Minas Gerais, Brazil.
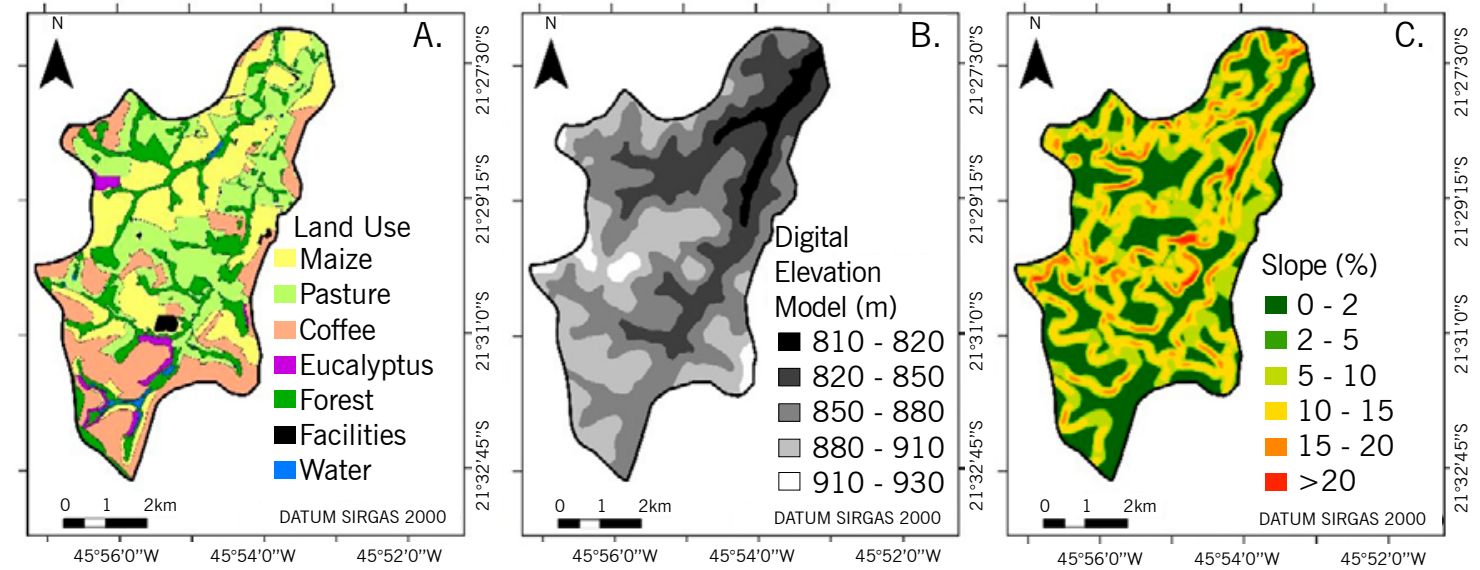

Source: Elaborated by the authors (2020).

In the watershed, altitudes vary between 810 and 930 m (FIGURE 2B). The Digital Elevation Model (DEM) was extracted from the contour lines of the state of Minas Gerais (SISEMA, 2019). Based on the DEM, the Slope Map was prepared. In the watershed, wavy relief predominates, with an average slope of $6.9 \%$ (FIGURE 2C).

\section{Revised Universal Soil Loss Equation (RUSLE)}

The RUSLE estimates the water erosion rate as Equation 1 (RENARD et al., 1997).

$$
A=R \cdot K \cdot L S \cdot C \cdot P
$$

At which: $\mathrm{A}$ is the mean annual soil loss, in $\mathrm{Mg} \mathrm{ha}^{-1}$ year $^{-1}$; $\mathrm{R}$ is the rainfall erodibility factor, in $\mathrm{MJ} \mathrm{mm} \mathrm{ha}^{-1} \mathrm{~h}^{-1} \mathrm{year}^{-1}$; $\mathrm{K}$ is the soil erodibility factor, in $\mathrm{Mg} \mathrm{ha}^{-1} \mathrm{MJ}^{-1} \mathrm{~mm}^{-1}$; $\mathrm{LS}$ is the topographic factor, by the relation between the length (L) and the ramp slope (S), $\mathrm{C}$ is the soil management and use land factor, and $\mathrm{P}$ is the factor conservationists practices, both dimensionless. 
The factor $\mathrm{R}$ represents the rainfall soil disaggregate and water erosion potential. The parameter was obtained from the South of Minas Gerais Erosivity Map developed by Aquino et al. (2012). About the soil erosive process resistance $(K)$, its values were determined to each watershed soil kind, basing on the related values present in specialized literature (BESKOW et al., 2009; OLIVEIRA et al., 2014).

The factor LS is an essential parameter to quantify the soil loss due to the topography surface flow velocity influence (BESKOW et al., 2009). The factor was calculated utilizing Equation 2, proposed by Moore and Burch (1986).

$$
\mathrm{LS}=\left(\frac{\mathrm{FA} \cdot 10}{22,13}\right)^{0.4} \cdot\left(\frac{\sin (\mathrm{S})}{0,0896}\right)^{1.3}
$$

At which: LS is the topographic factor, dimensionless; FA is the flow accumulation expressed as the DEM grid cell number; $\mathrm{S}$ is the watershed slope in degree and 10 is DEM spatial resolution do in meters.

Factor $\mathrm{C}$ relates the vegetal cover effects on the soil loss. The parameter varies from 0 to 1 , at which higher values represent low vegetal covering and higher rain impact and surface flow soil disaggregation (OLIVEIRA et al., 2014). Factor C was calculated as Durigon et al. (2014), utilizing the Normalized Difference Vegetation Index - NDVI (Equation 3).

$$
C=\frac{-N D V I+1}{2}
$$

At which: $\mathrm{C}$ is a soil cover factor and NDVI is the Normalized Difference Vegetation Index, both dimensionless.

The NDVI is a soil vegetal cover indicator that varies from -1 to +1 , with higher values attributed to areas with more vegetation. The index is calculated utilizing Equation 4 (TUCKER, 1979):

$$
N D V I=\frac{N I R-R E D}{N I R+R E D}
$$

At which: NIR and RED are near infra-red and red spectral bands, respectively.

The NDVI was calculated utilizing ArcMap 10.3 (ESRI, 2015) Raster Calculator tool from the bands 4 (red) and 5 (near infra-red) from Landsat-8 Operational Land Imager (OLI) image, used in the basin land use mapping.

Lastly, there is the factor $P$ that varies from 0 to 1 and its result represents the soil management effect about the erosive rates. The factor $P$ was calculated using the declivity as a determinant property in the soil conservationists' practices adoption (Silva et al., 2010; Medeiros et al., 2016). To slopes lower than $5 \%$, the P-value was 0.6 , and to slopes higher than $20 \%$, the P-value was 1 . In slopes among $5 \%$ to $20 \%$, the $P$ value is calculated as Equation 5 .

$$
P=0,69947-0,08911 \cdot s+0,01184 \cdot s^{2}-0,000335 \cdot s^{3}
$$

At which: $\mathrm{P}$ is the conservation practices factor, dimensionless, and $\mathrm{s}$ is the slope in $\%$. 
The stages of modeling, treatment and spatialization of data, as well as the making of maps of use and soil classes, MDE and slope, were performed using the software ArcMap 10.3 (ESRI, 2015).

\section{Results and discussion}

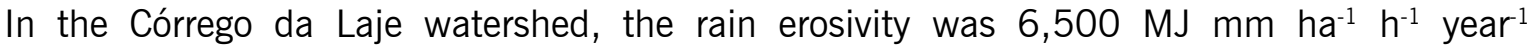
(AQUINO et al., 2012). Considering the classification proposed by Foster et al. (1981), the basin present a high erosivity class. The factor $\mathrm{K}$ was adapted by Sá et al. (2004) and Mendes Júnior et al. (2018) with values of 0.033 and $0.019 \mathrm{Mg} \mathrm{ha}^{-1} \mathrm{MJ}^{-1} \mathrm{~mm}^{-1}$ to the PVAe e LVd, respectively. Due to the pedological characteristics, PVAe are more prone to erosion than LVd.

The highest values of LS were observed in areas of a high slope, where the velocity of the runoff is greater (FIGURE 3A). In about $4 \%$ of the watershed, the LS values were greater than 10 and these areas can be considered highly vulnerable to erosion. Therefore, soil conservation practices should be implemented primarily in these areas, to reduce the energy gain from runoff due to topography (BESKOW et al., 2009; STEINMETZ et al., 2018).

Figure 3 - Topographic factor - LS (3A), NDVI (3B) and Soil cover factor - C (3C) of Córrego da Laje watershed, Alfenas, south of Minas Gerais, Brazil.
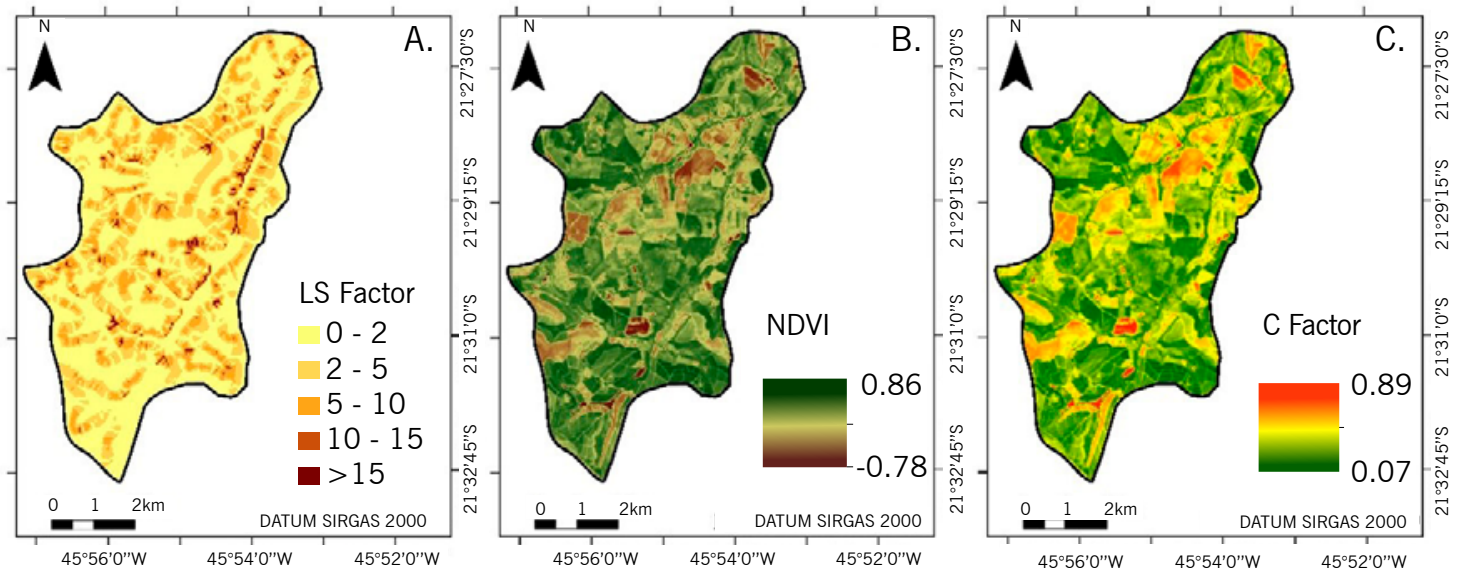

Notes: NDVI: Normalized Difference Vegetation Index; Factor LS, NDVI, Factor C: dimensionless.

Source: Elaborated by the authors (2020).

NDVI results were higher in areas with high plant density and lower in areas with exposed soil and areas with no soil (water and improvements) (FIGURE 3B). As for factor C, it is normalized between the values 0 and 1 and inversely proportional to the NDVI, thus the areas with the highest vegetation coverage presented the lowest value for factor C (FIGURE 3C).

It is worth mentioning that the determination of factor $\mathrm{C}$ from NDVI allows a more accurate representation when compared to methods based on values reported in the specialized literature, which were often developed for different regions of the study area. Also, with the use of NDVI in a GIS environment, factor $\mathrm{C}$ is calculated cell by cell over the entire area, and thus represents more realistically the heterogeneity of the vegetation cover.

RUSLE estimated the average soil loss in the Córrego da Laje watershed at $26.80 \mathrm{Mg} \mathrm{ha}^{-1}$ year $^{-1}$ with a predominance of high intensity erosive rates ( $>15 \mathrm{Mg} \mathrm{ha}^{-1}$ year ${ }^{-1}$ ), according to the proposed 
classification by Avanzi et al. (2013). The areas with intense erosion were concentrated mainly in the places with the highest declivity and, consequently, higher values of the LS factor (FIGURE 4).

Figure 4 - Córrego da Laje watershed soil loss spatial distribution, Alfenas, south of Minas Gerais, Brazil.

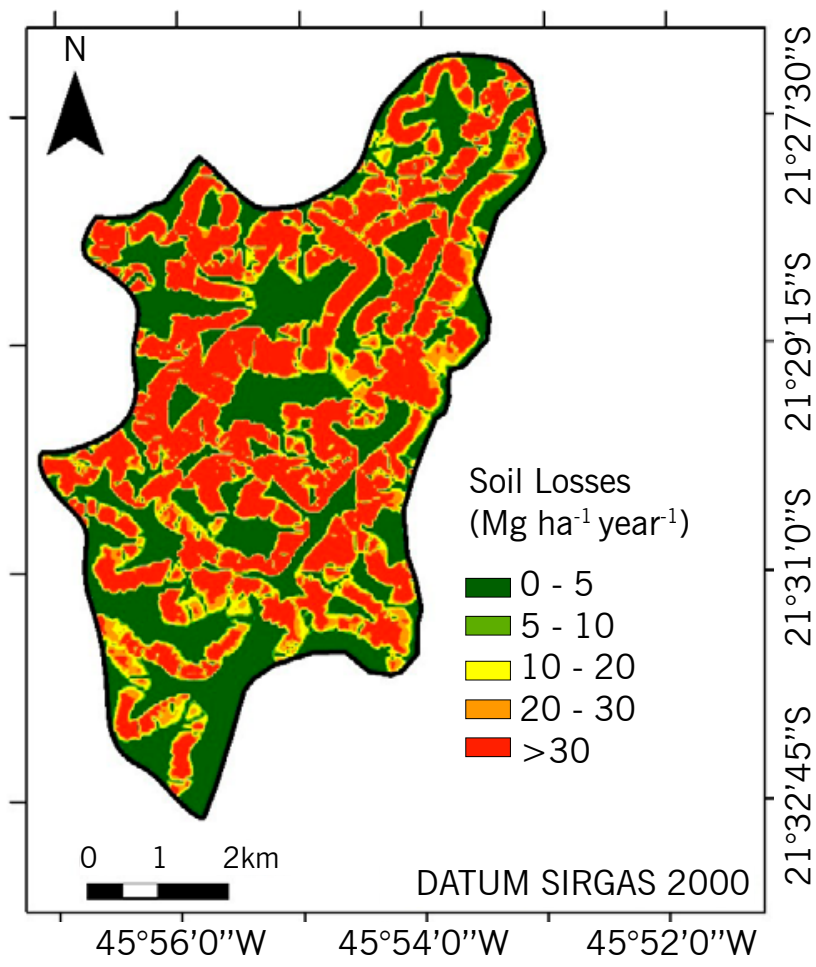

Source: Elaborated by the authors (2020).

The highest values of soil loss were observed in pasture areas (35.87 $\mathrm{Mg} \mathrm{ha}^{-1}$ year $^{-1}$ ), due to degradation, and in areas with maize cultivation (32.05 $\mathrm{Mg} \mathrm{ha}^{-1}$ year $^{-1}$ ) due to exposure of the soil at the time of sowing. In the other classes of land use, soil losses ranged from 15.00 and $20.40 \mathrm{Mg} \mathrm{ha}^{-1}$ year $^{1}$, which was provided by the higher plant density and consequent lower value of factor $\mathrm{C}$. The areas covered with water and improvements were not considered when estimating water erosion because they did not participate in the generation of sediments. Mendes Júnior et al. (2018) and Tavares et al. (2019), when modeling water erosion in a sub-basin of Córrego da Laje, with predominant coffee cultivation on conservation practices, observed erosion rates well below the results of the present work, demonstrating the importance of soil management practices on losses of soil.

As for water erosion in each type of soil, the generation of sediments was higher for PVAe (39.80 Mg ha-1 year-1) compared to LVd (23.70 Mg ha-1 year-1) due to its greater erodibility (K). This result reveals the importance of the soil's intrinsic attributes about natural protection against water erosion (OLIVEIRA et al., 2014).

As the areas with high soil losses (> $15 \mathrm{Mg} \mathrm{ha}^{-1}$ year $^{-1}$ ) are distributed over the entire length of the watershed, a broad plan for mitigating water erosion must be adopted, aiming at the introduction of conservationist practices. Among these practices, those aimed at improving soil covers, such as no-tillage in maize areas, the management of inter-plant vegetation in coffee cultivation and the recovery of degraded pastures, can be mentioned. In places with high declivity, level crops and terraces can be introduced, to minimize the flow speed. 
The modeling results are an important tool for planning the adoption of targeted conservation practices in the Córrego da Laje watershed, to reduce the direct damage from water erosion such as loss of nutrients and soil organic matter and indirect ones, such as silting Córrego da Laje and the reservoir of the Furnas Hydroelectric Plant.

\section{Conclusion}

The Revised Universal Soil Loss Equation identified the areas with the highest erosion rates in the Córrego da Laje watershed on steep slopes and in places with low vegetation cover, such as maize (32.05 Mg ha-1 year ${ }^{-1}$ ) and in degraded pastures (35.87 $\mathrm{Mg} \mathrm{ha}^{-1}$ year-1). It became evident that a broad plan to mitigate water erosion should be adopted, aiming at the introduction of conservationist practices, to reduce the environmental damage of the process.

\section{Aknowledgments}

The authors thank the Fundação de Amparo à Pesquisa do Estado de Minas Gerais (FAPEMIG) for the scholarship offered to the first author. This study was financed in part by the Coordenação de Aperfeiçoamento de Pessoal de Nível Superior - Brasil (CAPES) - Finance Code 001.

\section{Predição da erosão hídrica em uma bacia hidrográfica situada no sudeste brasileiro}

\section{Resumo}

A modelagem da erosão hídrica é uma forma rápida e precisa de estimar o potencial erosivo em bacias hidrográficas. Entre os modelos, temos a Equação Universal de Perda de Solo Revisada (RUSLE) que apresenta uma estrutura simples, com baixo custo de implementação e pode ser usada com informações prontamente disponíveis, contribuindo para o planejamento de práticas de conservação do solo. Nesse contexto, o objetivo do trabalho foi aplicar a RUSLE para estimar a erosão hídrica na bacia hidrográfica do Córrego da Laje afluente direto do reservatório da Usina Hidroelétrica de Furnas, situada no Sul de Minas Gerais, região do sudeste brasileiro. Nessa região a erosão hídrica é um grave problema que tem provocado o assoreamento do reservatório hidrelétrico e a depreciação da qualidade da água. As perdas de solo foram calculadas em Sistema de Informações Geográficas com base nas características topográficas, edafoclímaticas, na cobertura do solo e nas práticas de manejo. A perda de solo média da bacia hidrográfica foi de 26,80 $\mathrm{Mg} \mathrm{ha}^{-1} \mathrm{ano}^{-1} \mathrm{com}_{\text {predomínio de }}$ taxas erosivas de alta intensidade ( $>15 \mathrm{Mg} \mathrm{ha}^{-1} \mathrm{ano}^{-1}$ ). Considerando as classes de uso da bacia, a geração de sedimentos foi maior nas áreas de pastagem (35,87 $\left.\mathrm{Mg} \mathrm{ha}^{-1} \mathrm{ano}^{-1}\right)$ e nas áreas com cultivo de milho (32,05 $\left.\mathrm{Mg} \mathrm{ha}^{-1} \mathrm{ano}^{-1}\right)$. Como as áreas com erosão severa estão distribuídas em toda a extensão da bacia hidrográfica, deve ser adotado um amplo plano de mitigação da erosão hídrica a fim de reduzir os danos ambientais do processo.

Palavras-chave: Conservação do solo. Cobertura do solo. RUSLE. 


\section{Referências}

ALEWELL, C.; BORRELLI, P.; MEUSBURGER, K.; PANAGOS, P. Using the USLE: Chances, challenges and limitations of soil erosion modelling. International Soil and Water Conservation Research, Amsterdã, v. 7, n. 3, p. 203-225, 2019. Available at: https://doi.org/10.1016/j.iswcr.2019.05.004. Access on: 10 dez. 2019.

ALVARES, C. A.; STAPE, J. L.; SENTELHAS, P. C.; GONÇALVES, J. L. M.; SPAROVEK, G. Köppen's climate classification map for Brazil. Meteorologische Zeitschrift, Berlim, v. 22, n. 6, p. 711-728, 2013. Available at: https://doi.org/10.1127/0941-2948/2013/0507. Access on: 10 dez. 2019.

AQUINO, R. F.; SILVA, M. L. N.; FREITAS, D. A. F.; CURI, N.; MELLO, C. R.; AVANZI, J. C. Spatial variability of the rainfall erosivity in southern region of Minas Gerais state, Brazil. Ciência e Agrotecnologia, Lavras, v. 36, n. 5, p. 533-542, 2012. Available at: https://dx.doi.org/10.1590/S1413-70542012000500006. Access on: 10 dez. 2019.

AVANZI, J. C.; SILVA, M. L. N.; CURI, N.; NORTON, L. D.; BESKOW, S.; MARTINS, S. G. Spatial distribution of water erosion risk in a watershed with eucalyptus and Atlantic Forest. Ciência e Agrotecnologia, Lavras, v. 37, n. 5, p. 427-434, 2013. Available at: http://dx.doi.org/10.1590/S1413-70542013000500006. Access on: 10 dez. 2019.

BESKOW, S.; MELLO, C. R.; NORTON, L. D.; CURI, N.; VIOLA, M. R.; AVANZI, J. C. Soil erosion prediction in the Grande River Basin, Brazil using distributed modeling. Catena, Amsterdã, v. 79, n. 1, p. 49-59, 2009. Available at: https://doi.org/10.1016/j.catena.2009.05.010. Access on: 10 dez. 2019.

DECHEN, S. C. F.; TELLES, T. S.; GUIMARAES, M. F.; MARIA, I. C. Perdas e custos associados à erosão hídrica em função de taxas de cobertura do solo. Bragantia, Campinas, v. 74, n. 2, p. 224-233, 2015. Available at: https://doi.org/10.1590/1678-4499.0363. Access on: 06 jun. 2019.

DURIGON, V. L.; CARVALHO, D. F.; ANTUNES, M. A. H.; OLIVEIRA, P. T. S.; FERNANDES, M. M. NDVI time series for monitoring RUSLE cover management factor in a tropical watershed. International Journal of Remote Sensing, Londres, v. 35, n. 2, p. 441-453, 2014. Available at: http://dx.doi.org/10.1080/ 01431161.2013.871081. Access on: $10 \mathrm{dez} .2019$.

ESRI, Environmental Systems Research Institute - Inc. ARCGIS Professional GIS for the desktop version 10.3. Redlands, Califórnia, EUA, Software, 2015. Available at: http://desktop.arcgis.com/en/arcmap/10.3/ get-started/quick-start-guides/arcgis-desktopquick-start-guide.htm. Access on: 10 jan. 2019.

FOSTER, G. R.; MCCCOOL, D. K.; RENARD, K. G.; MOLDENHAUER, W. C. Conversion of the universal soil loss equation to SI metric units. Journal of Soil and Water Conservation, Ankeny, v. 36, n. 6, p. 355-359, 1981. Available at: http://www.jswconline.org/content/36/6/355.short. Access on: 10 dez. 2019.

GANASRI, B. P.; RAMESH, H. Assessment of soil erosion by RUSLE model using remote sensing and GIS A case study of Nethravathi Basin. Geoscience Frontiers, Amsterdã, v. 7, n. 6, p. 953-961, 2016. Available at: https://doi.org/10.1016/j.gsf.2015.10.007. Access on: 20 dez. 2019. 
HAIDARA, I.; TAHRI, M.; MAANAN, M.; HAKDAOUI, M. Efficiency of Fuzzy Analytic Hierarchy Process to detect soil erosion vulnerability. Geoderma, Amsterdam, v. 354, n. 1, p. 113853, 2019. Available at: https://doi.org/10.1016/j.geoderma.2019.07.011. Access on: 06 jun. 2019.

IGAM, Instituto Mineiro de Gestão das Águas. Plano Diretor de Recursos Hídricos da Bacia Hidrográfica do Entorno do Lago de Furnas. Instituto Mineiro de Gestão das Águas; Alago - Fupai. Belo Horizonte: IGAM, 2013. 305p

INMET, Instituto Nacional de Meteorologia. Estações pluviométricas convencionais. Ministério da Agricultura, Pecuária e Abastecimento (MAPA), 2019. Available at: http://www.inmet.gov.br/portal/index.php?r=bdmep/ bdmep. Access on: 10 dez. 2019.

INPE, Instituto Nacional de Pesquisas Espaciais. Divisão de Geração de Imagens (DIDGI). Ministério da Ciência, Tecnologia, Inovações e Comunicações, 2019. Available at: http://www.dgi.inpe.br/catalogo/. Access on: 10 dez. 2019.

MEDEIROS, G. O. R.; GIAROLLA, A.; SAMPAIO, G.; MARINHO, M. A. Estimates of Annual Soil Loss Rates in the State of São Paulo, Brazil. Revista Brasileira de Ciência do Solo, Viçosa, v. 40, e0150497, 2016. Available at: http://dx.doi.org/10.1590/18069657rbcs20150497. Access on: 10 nov. 2019.

MENDES JÚNIOR, H.; TAVARES, A. S.; SANTOS JÚNIOR, W. R.; SILVA, M. L. N.; SANTOS, B. R.; MINCATO, R. L. Water Erosion in Oxisols under Coffee Cultivation. Revista Brasileira de Ciência do Solo, Viçosa, v. 42, e0170093, 2018. Available at: https://dx.doi.org/10.1590/18069657rbcs20170093. Access on: 10 nov. 2019.

MOORE, I. D.; BURCH, G. J. Physical basis of the length slope factor in the Universal Soil Loss Equation. Soil Science Society of America, Washington, v. 50, n. 5, p. 1294-1298, 1986. Available at: https://doi.org/ 10.2136/sssaj1986.03615995005000050042x. Access on: 30 nov. 2019.

OLIVEIRA, V. A.; MELLO, C. R.; DURÃES, M. F.; SILVA, A. M. Soil erosion vulnerability in the verde river basin, southern Minas Gerais. Ciência e Agrotecnologia, Lavras, v. 38, n. 3, p. 262 269, 2014. Available at: http://dx.doi.org/10.1590/S1413-70542014000300006. Access on: 30 nov. 2019.

PRASANNAKUMAR, V.; VIJITH, H.; ABINOD, S.; GEETHA, N. Estimation of soil erosion risk within a small mountainous sub-watershed in Kerala, India, using Revised Universal Soil Loss Equation (RUSLE) and geo-information technology. Geoscience Frontiers, Amsterdã, v. 3, n. 2, p. 209-215, 2012. Available at: https://doi.org/10.1016/j.gsf.2011.11.003. Access on: 10 nov. 2019.

RENARD, K. G.; FOSTER, G. R.; WEESIER, G. A.; MCCOOL, D. K.; YODER, D. C. Predicting soil erosion by water: a guide to conservation planning with the Revised Universal Soil Loss Equation (RUSLE). Washington: United States Department of Agriculture, 1997. 384p.

RENSCHLERA, C. S.; MANNAERTS, C.; DIEKKRÜGER, B. Evaluating spatial and temporal variability in soil erosion risk-rainfall erosivity and soil loss ratios in Andalusia, Spain. Catena, Amsterdã, v. 34, n. 4, p. 209-225, 1999. Available at: https://doi.org/10.1016/S0341-8162(98)00117-9. Access on: $10 \mathrm{dez} .2019$. 
SÁ, M. A. C.; LIMA, J. M.; CURI, N.; MASSAROTO, J. A.; MARQUES, J. J. G. S. M. Estimativa da erodibilidade pela desagregação por ultra-som e atributos de solos com horizonte $B$ textural. Pesquisa Agropecuária Brasileira, Brasília, v. 39, n. 7, p. 691-699, 2004. Available at: http://dx.doi.org/10.1590/ S0100-204X2004000700011. Access on: 10 dez. 2019.

SILVA, F. G. B.; MINOTTI, R. T.; LOMBARDI NETO, F.; PRIMAVESI, O.; CRESTANA, S. Previsão da perda de solo na Fazenda Canchim - SP (EMBRAPA) utilizando geoprocessamento e o USLE 2D. Engenharia Sanitaria e Ambiental, Rio de Janeiro, v. 15, n. 2, p. $141^{-14} 48,2010$. Available at: http://dx.doi.org/10.1590/ S1413-41522010000200006. Access on: 10 dez. 2019.

SISEMA. Infraestrutura de Dados Espaciais do Sistema Estadual de Meio Ambiente e Recursos Hídricos. Belo Horizonte: IDE-Sisema, 2019. Available at: http://idesisema.meioambiente.mg.gov.br. Access on: 05 dez. 2019.

STEINMETZ, A. A.; CASSALHO, F.; CALDEIRA, T. L.; OLIVEIRA, V. A.; BESKOW, S.; TIMM, L. C. Assessment of soil loss vulnerability in data-scarce watersheds in southern Brazil. Ciência e Agrotecnologia, Lavras, v. 42, n. 6, p. 575-587, 2018. Available at: https://dx.doi.org/10.1590/1413-70542018426022818. Access on: 08 jan. 2020.

TAVARES, A. S.; SPALEVIC, V.; AVANZI, J. C.; NOGUEIRA, D. A.; SILVA, M. L. N.; MINCATO, R. L. Modeling of water erosion by the erosion potential method in a pilot subbasin in southern Minas Gerais. Semina: Ciências Agrárias, Londrina, v. 40, n. 2, p. 555-572, 2019. Available at: https://dx.doi.org/10.5433/16790359.2019v40n2p555. Access on: 08 jan. 2020.

TUCKER, C. J. Red and photographic infrared linear combination for monitoring vegetation. Remote Sensing of Environment, Amsterdã, v. 8, n. 2, p. 127-150, 1979. Available at: https://doi.org/10.1016/00344257(79)90013-0. Access on: 08 jan. 2020.

UNIVERSIDADE FEDERAL DE VIÇOSA; FUNDAÇÃO CENTRO TECNOLÓGICO DE MINAS GERAIS; UNIVERSIDADE FEDERAL DE LAVRAS; FUNDAÇÃ ESTADUAL DO MEIO AMBIENTE. Mapa de solos do Estado de Minas Gerais. Belo Horizonte: Fundação Estadual do Meio Ambiente, 2010. Available at: http://www.feam.br/noticias/1/949-mapas-de-solo-do-estado-de-minas-gerais. Access on: 08 nov. 2020.

WISCHMEIER, W. H.; SMITH, D. D. Predicting rainfall erosion losses. A guide to conservation planning. Washington DC: USDA, 1978. 537p.

WANG, X.; XUE, B.; YAO, S.; YANG, H.; GU, Z.; YANG, B.; ZHANG, M.; ZHU, Y. 137Cs estimates of soil erosion rates in a small catchment on a channelized river floodplain in the lower reaches of Yangtze River, China. Journal of Environmental Radioactivity, Amsterdam, v. 208, n. 1, p. 106008, 2019. Available at: https://doi.org/10.1016/j.jenvrad.2019.106008. Access on: 06 jun. 2019.

Received: January 08, 2020

Accepted: June 10, 2020 